\title{
COVID-19 Pandemic, Part II: What to Do and Who Is to Blame? Viruses as Part of a Necessary Ecosystem, Possible Prophylactic Medication, Immunity
}

\author{
Ilia Brondz \\ Norwegian Drug Control and Drug Discovery Institute (NDCDDI), Ski, Norway \\ Email: ilia.brondz@gmail.com
}

How to cite this paper: Brondz, I. (2021). COVID-19 Pandemic, Part II: What to Do and Who Is to Blame? Viruses as Part of a Necessary Ecosystem, Possible Prophylactic Medication, Immunity. Voice of the Publisher, 7, 98-116.

https://doi.org/10.4236/vp.2021.73009

Received: June 3, 2021

Accepted: September 11, 2021

Published: September 14, 2021

Copyright ( 2021 by author(s) and Scientific Research Publishing Inc. This work is licensed under the Creative Commons Attribution International License (CC BY 4.0).

http://creativecommons.org/licenses/by/4.0/

\section{(c) (i) Open Access}

\begin{abstract}
This is the second paper in the series. The problems connected with the COVID-19 pandemic are of interest to all readers independent of the main aim and scope of the journal. In the series of the "COVID-19 Pandemic", the author's views and facts are presented and discussed. In the third paper in this series, we will discuss the usefulness versus harmfulness of the actions during the pandemic and several theories about the origin of the problem. In the paper "COVID-19 Pandemic, Part I", it was demonstrated that the author has no doubt that viruses are living organisms like many other living organisms and are a part of the ecosystem. Viruses were the first living organisms that appeared on the Earth. Many of the theories accepted today do not represent the true state of the art about the appearance of life on Earth and the role of viruses. This paper will describe the author's view about viruses and the interaction of viruses with other organisms, the harmfulness of a toxic environment as the trigger for epidemics, and the usefulness of medication for COVID-19 illness.
\end{abstract}

\section{Keywords}

COVID-19 Pandemic, Virus, Toxic Environment, Trigger for Epidemics, Medication for COVID-19

\section{Introduction}

In the earlier stages of the existence of the Earth, the conditions on the planet were quite different from those of today. The appearance of organic molecules including amino acids and small peptides was possible; however, organization 
from such a mixture of distinct simple living organisms with the ability to reproduction is an incorrect hypothesis. Then, as today, the blueprints for reproduction, i.e., nucleotide and nucleoside molecules, were needed as the organizers. These stable molecules with a ring structure with tri- and pentavalent nitrogen are most suitable for elevated temperatures (Brondz, 2021). The first building blocks of life were these thermodynamically stable tri- and pentavalent nitrogen ring structures (Brondz, 2021). They were the primary manifestation of life, which organized peptides into simple proteins, and simple proteins into simple living, self-reproducing organisms-viruses (Brondz, 2020). It is difficult to imagine that any living, self-reproducing organisms had appeared before the appearance of the genetic and ribosomal material comprising viruses. Viruses are quite simple organisms that today are intracellular parasites, which often cause the death of the infected cells. However, parasitism was not the primary aim of viruses; at the beginning, they were possibly predators for other types of viruses or even cannibalized each other. Once cells appeared, viruses started to use the cells as their prey and later became intracellular parasites. As occurs for all parasites over long-term evolution, they underwent simplification and adaptation to parasitism. Thus, viruses were transformed into simpler organized structures and lost many of their organelles and even parts of their genetic material.

Not all cells that are infected by viruses die. Some nontarget cells infected by virions stay alive after infection and even after the viral particles have left those cells.

Rubella is a contagious disease caused by infection with the rubella virus (Lambert et al., 2015), (Carlson et al., 2016). Infection with this virus may result in a child being born with congenital rubella syndrome (CRS) (Lambert et al., 2015), the symptoms of which include coryza (which may convert to pneumonia (Michael, 1908)) and CRS can manifest as effects on the heart and brain (Lambert et al., 2015). Cytomegalovirus is a common virus that affects most humans. Its host organisms are humans and monkeys. Those who have been infected by cytomegalovirus have it for life. There is no curative treatment to eliminate this virus, although therapies exist (Mattes et al., 2000). For young and healthy individuals with a good immune system, the infection is a minimal problem, however, during pregnancy or in immunocompromised humans it can threaten health. Many viruses are retained in infected organisms for their lifetime, others can remain a part of their genome incorporated into the genome of the host when they leave the nontarget cell.

The target cells of the common flu virus are mucosal cells, but it also infects other cell types, including ovaries, and spermatozoids. Not all these cells die; some remain alive and are capable of performing their functions. Thus, fertilization can proceed normally, and the resulting babies may even be without defects. However, in some cases, the following generation is defective. Part of the viral genetic material can remain attached to the original genetic material of infected subjects (human, animal, plant, bacteria, or other). In these cases, the defects can 
be negative (i.e., they result in illnesses or even death), or positive (i.e., they result in additional capabilities). These defects are mutations. If part of the viral genome remains incorporated in these cells it can affect the next generation or be transmitted along through generations and affect newborns of the third, fourth, or many generations afterward, as in the case of hemophilia (a mostly inherited genetic disorder that impairs the body's ability to make blood clots).

\section{Role of Virus in the Environment}

Charles Darwin described the appearance of species in "On the Origin of Species" (Darvin, 1859), (Freeman, 2002) in 1859 at a time when its genetic basis was unknown. His theory was based mainly on observation of natural selection without any understanding of the role of genetic' mutation in the appearance of changes in a species. This theory is incorrect. Without mutation, the appearance of a new species is not possible. Gregor Johann Mendel (Czech: Řehoř Jan Mendel) is recognized as the founder of the modern science of genetics (Klein \& Klein, 2013), who formulated the laws of Mendelian inheritance (Schacherer, 2016). These laws were originally proposed by Gregor Mendel in 1865 and 1866, and rediscovered in 1900. The principles of the initially controversial Mendelian theories were integrated with the Boveri-Sutton chromosome theory of inheritance by Thomas Hunt Morgan in 1915, and the combined theory became the core of classical genetics. The role of viruses in generating positive mutations resulting in the dominance of strong mutants and the disappearance of weak mutants was underestimated by Charles Darwin, although it was unknown to him. Mutations resulting from chemical or radioactive causes are usually rare and lead to defects or weak mutants. Mutations are more frequently caused by the involvement of viruses, which are the driving force in the appearance of both negative and positive mutations. Thus, viruses are the driving force behind the appearance of new species by inducing mutation and subsequent selection of strong mutants.

\section{Comparative Situation}

In a previous paper (Brondz, 2020), I presented the dangers of agricultural customs such as using the manure from pigs, which is a source of a range of infections including coronaviruses. Some pesticides and insecticides deactivate lysozyme, thus jeopardizing host immunity. In another paper (Brondz, 2017c), I warned strongly against the custom of using "fire farming" or "fire-stick farming" in agriculture and the blind eye turned by authorities to annual forest fires that are started deliberately. The accumulation of dioxins in the environment as a result of "fire farming" and "fire-stick farming" has led to disease in countries such as India, and dioxins can lead to mutations in viruses, which is a possible cause of the different dynamics of the epidemic in India and China (in India "fire farming" is a common custom, but in China, it is virtually unknown). 
However, the use in China and elsewhere in Asia of "gutter oil" by street kitchens. (The Making of "Gutter Oil"

(https://www.youtube.com/watch?v=zrv78nG9R04)) can lead to the same problems as "fire farming" in India because the oil contains several different carcinogens. In both cases, the presence of carcinogens and dioxins is a fact. Dioxins, most pesticides, insecticides, radiation, heavy metal elements, all carcinogens, and many other environmental pollutants are jeopardizing human immunity and the immunity of other living creatures including even plants. Immunocompromised animals are a significant reservoir of dangerous infections (including viral infections) for humans. The substances listed above can trigger mutations in fungi, molds, bacteria, and viruses. The appearance of a new mutant COVID-19 in India could be predicted because of contamination of the environment by dioxins and is not surprising. In a previous paper (Brondz, 2017c), I provided an alert that "fire farming" is a significant crime against the population in these countries and against consumers worldwide who consume the contaminated products. In another paper (Brondz \& Brondz, 2011), I presented clear evidence that some chlorinated pesticides can deactivate lysozyme. Lysozyme is a part of the humoral immune system that is present in all mucosal tissues and protects humans from the first minute of life (Minami et al., 2015). Lysozyme exhibits activity against viral infections (Oderinde et al., 2017; Cisani et al., 1984; Lee-Huang et al., 1999). Deactivation of lysozyme by chemicals and pesticides jeopardizes the immune system.

\subsection{Anti-COVID-19 Medication: Chloroquine}

In China, immediately after the outbreak of COVID infection in 2019, it was proposed to use chloroquine as a treatment. Chloroquine is a 4 -aminoquinoline antimalarial drug.

Chloroquine Figure 1 was the first synthetic antimalarial drug (Brondz, 2011a); however, it is quite toxic. Other synthetic antimalarial drugs (primaquine, pamaquine, quinocide, and tafenoquine) are less toxic but have similar pharmacological and biochemical mechanisms to chloroquine. Figure 2 shows the structures of (a) primaquine, (b) quinocide, and (c) pamaquine. Their efficacy against COVID-19 may be based on their overall effects, in particular the arrest or inhibition of proton pumps.

\subsection{Anti-COVID-19 Medication: Primaquine, Quinocide, and Pamaquine}

The effects of contamination with quinocide in primaquine were studied using chromatography and mass spectrometry, and some of its biochemical toxicity analyzed in vitro. The toxicity (in vitro) was first presented as a poster see Figure 3 (Brondz et al., 2003) (below) and later published as a complete paper (Brondz et al., 2004a). A new gas chromatography-mass spectrometry (GC-MS) method of analysis of the toxic contaminant quinocide in primaquine was developed and presented in (Brondz et al., 2004a, 2004b) (see Figure 4), and later 


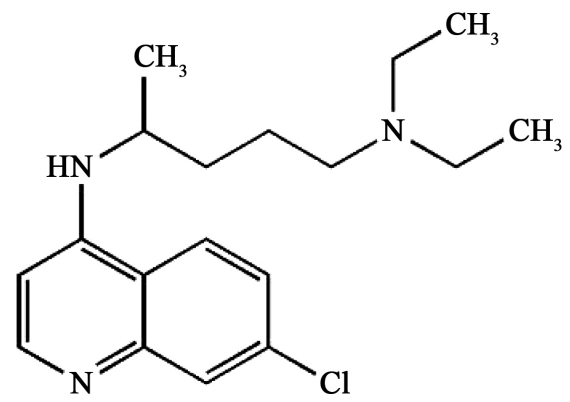

Figure 1. Structure of chloroquine, a 4-aminoquinoline.<smiles>COc1cc(NC(C)CCCN)c2ncccc2c1</smiles>

(a)<smiles>COc1cc(NCCCC(C)N)c2ncccc2c1</smiles>

(b)<smiles>CCN(CC)CCCC(C)Nc1cc(OC)cc2cccnc12</smiles>

(c)

Figure 2. (a) Primaquine, (b) quinocide, and (c) pamaquine. Primaquine, quinocide, and pamaquine are 8 -aminoquinolines.

published as a complete paper (Brondz et al., 2005a). A subsequent series of papers supported the findings (Brondz et al., 2004a), (Brondz et al., 2005a), (Brondz et al., 2005b), (Brondz \& Klein, 2005), (Brondz et al., 2005c), (Brondz \& Klein, 2006), (Brondz et al., 2007), (Brondz et al., 2009), (Brondz, 2009a), (Brondz, 2009b), (Brondz, 2010), (Brondz, 2011b), (Brondz \& Brondz, 2012a), (Brondz, 2014), (Brondz, 2011c). In references (Brondz et al., 2003) and (Brondz et al., 2004a), algicidal activity on Chlamydomonas reinhardtii strain CC124 was used as a measure of biological toxicity. The details of biological toxicity were presented at (Brondz, 2011b).

The effects of contamination with quinocide were studied using chromatography and mass spectrometry, and some of its biochemical toxicity analyzed in vitro. The toxicity (in vitro) was first presented as a poster see Figure 3 (Brondz et al., 2003) (below) and later published as a complete paper (Brondz et al., 2004a, 2004b). A new chromatography-mass spectrometry method of analysis of the toxic contaminant quinocide in primaquine was developed and presented in (Brondz et al., 2003) (see Figure 4), and later published as a complete paper 


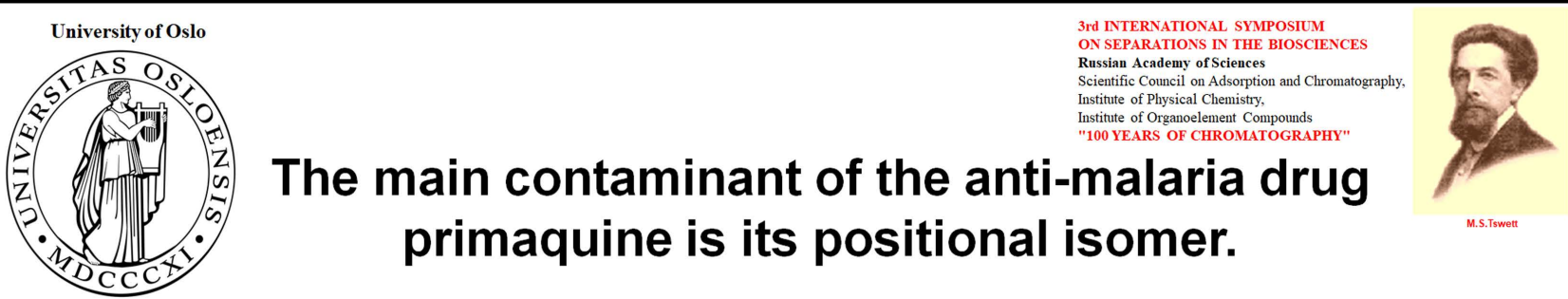

\title{
ILIA BRONDZ1 ${ }^{\star}$, DIMITRIS MANTZILAS ${ }^{1}$, UWE KLEIN², MARINA N. LEBEDEVA, FELIX S. MIKHAILITSYN³, GASAN D. SOULEIMANOV ${ }^{3}$
}

\author{
${ }^{1}$ Department of Biochemistry, University of Oslo, P.O.Box 1041, Blindern, 0316 Oslo, Norway \\ ${ }^{2}$ Department of Biology, University of Oslo, P.O.Box 1052, Blindern, 0316 Oslo, Norway \\ ${ }_{3}^{3}$ Martsinovsky Institute of medical parasitology and tropical medicine, 20 Malaja Pyrogovskaja st., Moscow, Russia
}

The aim of this work was to find the nature of the main contaminant of the anti-malaria drug primaquine.

Malaria is a widely spread protozoan disease with a death rate of 1.5 million humans per year. The micro organisms that cause malaria in humans are Plasmodium falciparum, P. vivax, $P$. ovale and $P$. malariae. Primaquine diphosphate, 8-[(4-amino-1-methylbutylamino)]-6-methoxyquinoline di-(dihydrogen phosphate) and quinocide 8-[ (4-amino-4-methyl- butylamino)]-6-methoxyquinoline are the only antimalarial drugs, which are gametocidal and effective against the hypnozoites, and against the tissue schizonts. Primaquine is not effective against blood schizonts. Synthetic antimalarials have been developed in Germany and France before the World War II and in Great Britain, the USA, and the USSR during and since the World War II. Out of the thousands of compounds investigated, only a few have achieved a significant place in the chemotherapy of malaria. The most important of the synthetic antimalarials being currently used are chloroquine, amodiaquine, primaquine, proguanil, and pyrimethamine. The plasmocide and quinocide have been widely used in the USSR. Synthesis of primaquine has been proposed by Elderfield et al., 1946. An improved procedure was also proposed by Elderfield et al., 1955. The latter procedure is still in use today. Synthesis of quinocide was described by Braude and Stavrovskaya in 1956.

Circular dichroism (CD) analysis [Fig 1] revealed that primaquine is an optical active substance. Thus primaquine is not a racemic mixture and the presence of other isomers is possible. The appearance of different isomers, beside of optical, is possible under the synthesis of primaquine [Fig 2]. Two different methods of high pressure liquid chromatography (HPLC) was use to study contaminants in the drug primaquine. The first HPLC system was equipped with a chiral Chirex (S) - VAL and (R) -NEA column [Fig 3] and the second system was equipped with an Adsorbosphere Nucleotide-Nucleoside $7 \mu$ column [Fig 4, 5]. Comparison of the main contaminant of primaquine with an authentic quinocide standard by using co-chromatography in both HPLC systems supported the hypothesis.

The alga Chlamydomonas reinhardtii, strain CC124 was used to assess the toxicity of primaquine (containing $0.3 \%$ of quinocide), primaquine (containing $5.8 \%$ quinocide), and quinocide. The effect on uptake of oxygen in the dark (respiration) and production of oxygen in light (photosynthesis) was determined for all samples. Because primaquine and quinocide reverse oxygen production in the light to oxygen consumption, these substances seem to interfere with the photosynthetic electron transport chain in the chloroplast of the algae [Tab 1,2]

Fig 1
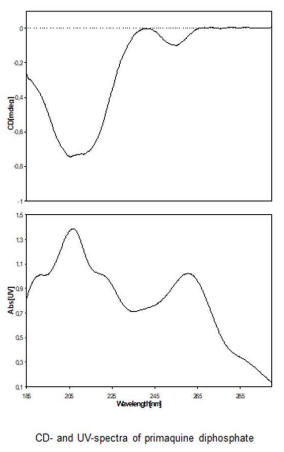

Fig 4

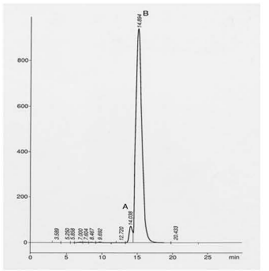

Reverse phase chromatogentr

Acknowledgments

The authors express gratitude to engineer John Vedde Department of Chemistry, Laboratory of Mass-spectrometry, University of Oslo, Norway, for technical assistance, to the Counsellor of Embassy of the Russian Federation in Norway Vladimir Kravchenko an the Regional Coordinator of the Roll Back Malaria World Health Organization Regional Office for Europe Dr. Mikhail Ejov, Danmark, for establishing contacts with the Russian
Fig 2

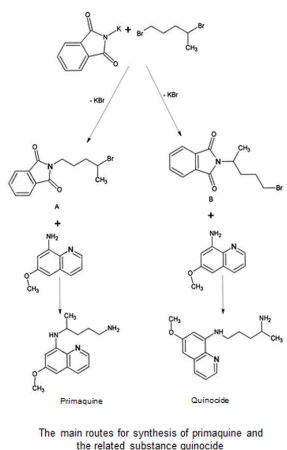

Fig 5
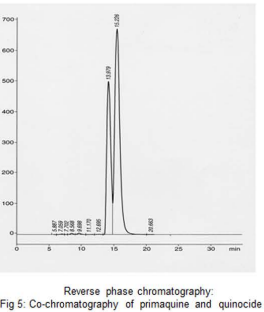
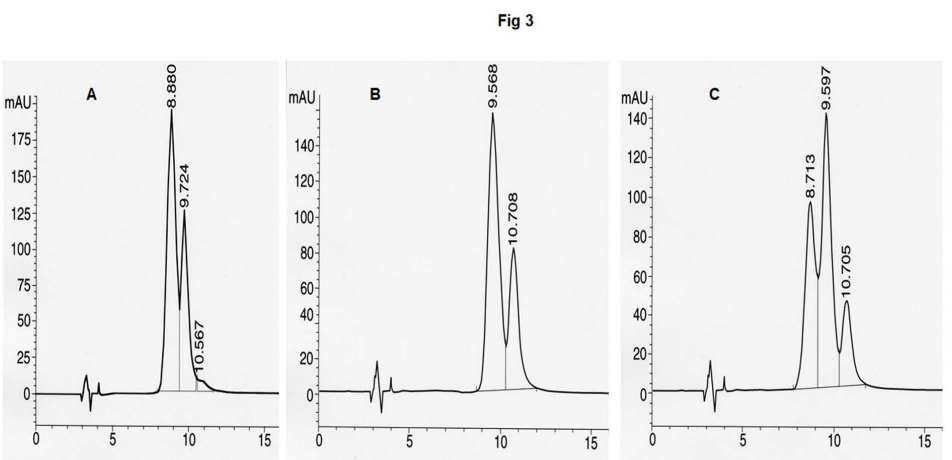

A) Primaguine. B) Quinocide. C. C) Cochromomatogragaphy of pimaquine and quinocide
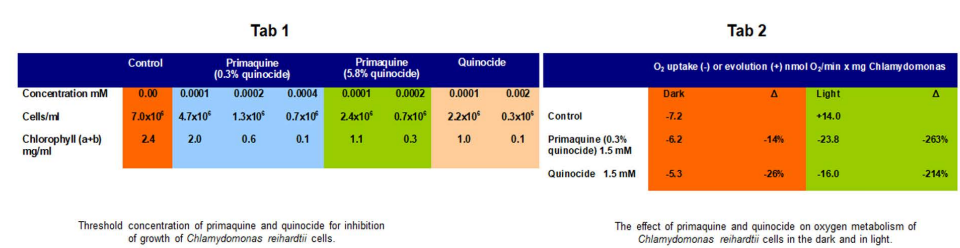

The effect of primanuine and quincocide on oxygen metablism of

It is concluded that the main contaminant of the anti-malaria drug primaquine is its positional isomer. The primaquine drug is not a racemate but a mixture of positional isomers in the $d$ - and $l$-forms. Minor amounts of other related substances or contaminants can contribute more to the toxicity of primaquine than the $6 \%$ of the positional isomer quinocide.

Figure 3. The first time the biochemical toxicity (in vitro) was presented as a poster (reproduced from Brondz et al., 2003). 


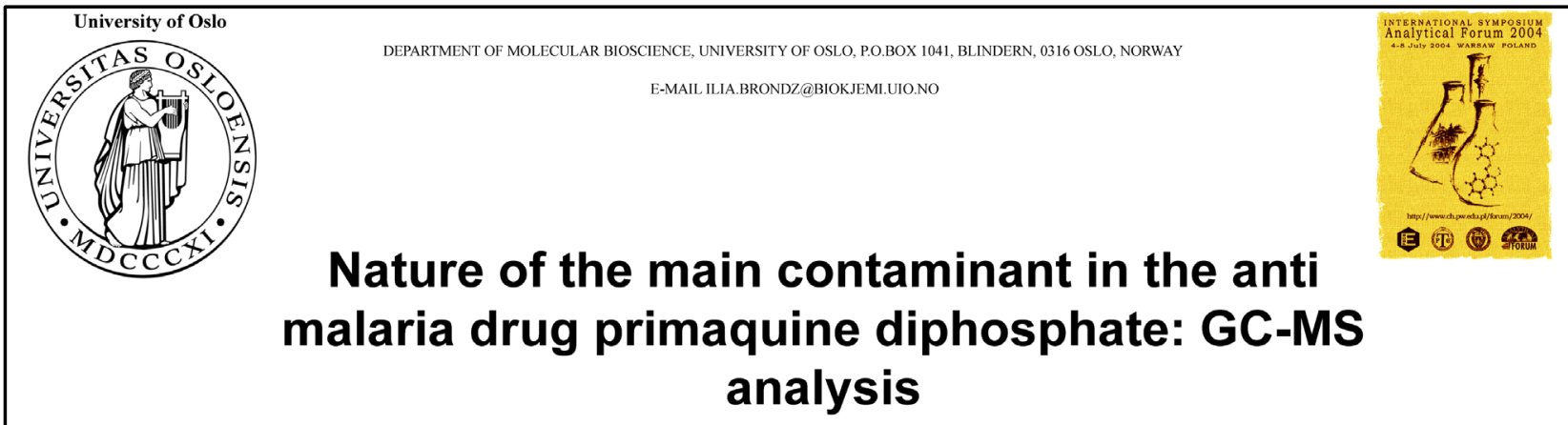

\author{
ILIA BRONDZ ${ }^{*}$, DAG EKEBERG², UWE KLEIN', DIMITRIS MANTZILAS', ERLEND HVATTUM², HENRIK SCHULTZ \\ AND FELIX MIKHAILITSIN \\ 'DEPARTMENT OF MOLECULAR BIOSCIENCE, UNIVERSITY OF OSLO, PO.BOX 1041, BLINDERN 0316 OSLO, NORWAY \\ MOLECULAR BIOSCIENCE, UNIVERSITY OF OSLO, P.O.BOX 1041, BLINDERN, 0316 OSLO, NORWAY \\ 3WEIFA AS, HAUSMANNS GT. 6, P.OBOX A9113 GRONLAND, 0133 OLLO, NORWAY
4MARTSINOVSKY INSTITUTE OF MEDICAL PARASITOLOGY AND TROPICAL MEDICINE, 20 MALAJA PYROGGOVKAJA ST. MOSCOW, RUSSIA
}

The aim of this work was to find the GC, GC-MS method to detect quinocide contaminant in the anti-malaria drug primaquine without of to use the quinocide as the standard.

MALARIA IS ONE OF THE MOST WIDE-SPREADLY DISEASES ON THE GLOBE WITH AN ESTIMATED CASE RATE UP TO 300-500 MILLION AND A DEATH RATE OF ABOUT 2.7 MILLION HUMANS PER YEAR. MALARIA IS A PROTOZOAN (PLASMODIUM) DISEASE. THE DRUG PRIMAQUINE DIPHOSPHATE IS USED FOR CAUSATIVE (RADICAL) TREATMENT OF PLASMODIUM VIVAX INFECTIONS. THE DRUG IS GAMETOCIDAL AND EFFECTIVE AGAINST THE HYPNOZOITES AND TISSUE SCHIZONTS. THE NOTION THAT THE MAIN CONTAMINANT IN THE DRUG PRIMAQUINE IS ITS STEREO-ISOMER WAS STUDIED IN OUR LABORATORY. USING HPLC AND HPLC-MS WE WERE ABLE TO SHOW THAT THE MAIN CONTAMINANT OF PRIMAQUINE IS NOT THE STEREO-ISOMER BUT THE POSITIONAL ISOMER QUINOCIDE. PRIMAQUINE AND QUINOCIDE ARE HIGHLY TOXIC SUBSTANCES THAT CAN HAVE A NUMBER OF SIDE EFFECTS UNDER TREATMENT. THE AVAILABILITY OF QUINOCIDE FOR USE AS A STANDARD IS LIMITED DUE TO A HALT IN PRODUCTION OF THE SUBSTANCE IN THE FORMER USSR, WHICH WAS THE ONLY PRODUCER OF QUINOCIDE. BECAUSE BOTH THE UV SPECTRUM AND THE MS FRAGMENTATION IN HPLC-MS OF PRIMAQUINE AND QUINOCIDE ARE VERY SIMILAR, IT IS DIFFICULT TO PROVE THE IDENTITY OF THESE SUBSTANCES BY THESE TECHNIQUES WITHOUT A STANDARD. PROVING THE IDENTITY OF CONTAMINANTS, ESPECIALLY HIGH TOXIC CONTAMINANTS, IN HUMAN MEDICINES IS IMPORTANT AND THEREFORE NECESSITATED DEVELOPMENT OF ADDITIONAL TECHNIQUES TO SECURE PROPER IDENTIFICATION OF COMPOUNDS IN THE DRUG PRIMAQUINE.

Synthetic anti-malarials have been developed in Germany and France before the World War II and in Great Britain, the USA and the USSR during and since the World War II.

Synthesis of primaquine has been proposed by Elderfield et al., 1946, Fig. 1. An improved procedure was also proposed by Elderfield et al. 1955. The latter procedure is still in use today. Synthesis of quinocide was described by Braude and Stavrovskaya in 1956.

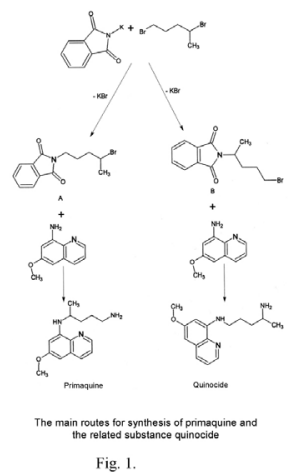

Fig. 1.

MS FRAGMENTATION OF PRIMAQUINE IS QUINOCIDE IS POORLY COVERED IN THE LITERATURE.

MS FRAGMENTATION

DIFFERENCES BETWEEN

PRIMAQUINE AND QUINOCIDE

(FIG. 3 A AND B; A,

FRAGMENTATION OF

PRIMAQUINE; $\mathrm{B}$,

FRAGMENTATION OF

QUINOCIDE).
IN THE PRESENT WORK WE USED GCMS TO PROVIDE CHROMATOGRAPHIC EVIDENCE FOR THE GC SEPARATION OF QUINOCIDE FROM PRIMAQUINE RT ON THE CHROMATOGRAM (FIG. 2 A, B AND C; A, PRIMAQUINE; B, QUINOCIDE; C, CO-

CHROMATOGRAPHY OF PRIMAQUINE AND QUINOCIDE IN MIXTURE).
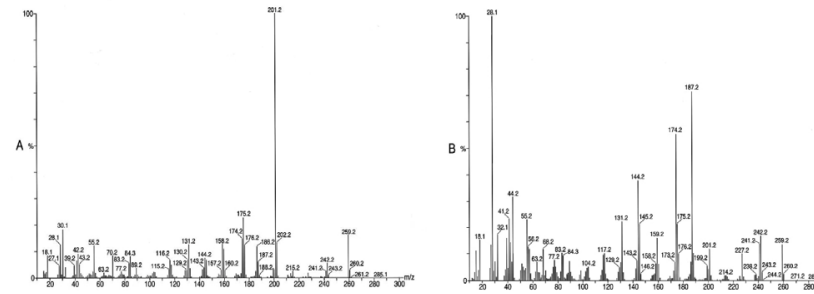

romatography of the drug primaquine and quinocide Fig. 2 .

PRIMAQUINE AND QUINOCIDE ARE READILY EPARATED BY GC. BOTH SUBSTANCES GAVE VISIBLE M+ MOLECULAR IONS $259 \mathrm{~m} / \mathrm{z}$ THE BASE PEAK IN MASS SPECTRA OF
PRIMAQUINE WAS FOUND TO BE AT $\mathrm{m} / \mathrm{z} 201$.

IN MASS SPECTRA OF THE POSITIONAL-ISOMER OUNOCIDE THE BASE PEAK WAS FOUND TO B AT $m / z 187$.

THE IONS FOUND AT $\mathrm{m} / \mathrm{z} 30$ AND $\mathrm{m} / \mathrm{z} 44$ ARE ALSO IMPORTANT FOR IDENTIFICATION ANI OF THE TERIZATION OF TS

Figure 4. The new GC-MS method of analysis of the toxic contaminant quinocide in primaquine (reproduced from Brondz et al., 2004b). 
(Brondz et al., 2005a). A subsequent series of papers supported the findings (Brondz et al., 2004a, 2004b), (Brondz et al., 2005a), (Brondz et al., 2005b), (Brondz \& Klein, 2005), (Brondz et al., 2005c), (Brondz \& Klein, 2006), (Brondz et al., 2007), (Brondz et al., 2009), (Brondz, 2009a), (Brondz, 2009b), (Brondz, 2010), (Brondz, 2011b), (Brondz \& Brondz, 2012a), (Brondz, 2014), (Brondz, 2011c). In references (Brondz et al., 2003) and (Brondz et al., 2004a), algicidal activity on Chlamydomonas reinhardtii strain CC124 was used as a measure of biological toxicity. The details of biological toxicity were presented at (Brondz, 2011b). The table of toxic effects is shown in Figure 5

[https://www.researchgate.net/publication/264346815_In_vitro_techniques_in_anal ysis_of_antimalarial_drug_primaquine_Historical_Overview_of_Chromatography_ and_Related_Techniques_in_Analysis_of_Antimalarial_Drug_Primaquine].

$C$. reinhardtii is a well-studied biological model organism (Figure 6). Several effects of primaquine on $C$. reinhardtii have been described (Brondz et al., 2003). However, the immobilization by toxic actions of primaquine and quinocide of movements of this motile alga was only partly studied (Brondz et al., 2003). The main contaminant of the anti-malaria drug primaquine is its positional isomer (Brondz et al., 2004a; Brondz, 2011b).

Figure 6 scheme of the Chlamydomonas reinhardtii cell; schematically redrawn, based on this TEM micrograph: http://cellimagelibrary.org/images/CIL_37252 1) flagellum 2) mitochondrion 3) contractile vacuole 4) eyespot (stigma) 5) chloroplast 6) Golgi apparatus 7) starch granules 8) pyrenoid 9) vacuole 10) nucleus 11) endoplasmic reticulum 12) cell membrane 13) cell wall. (Image corresponds to Figure 2 in J. Cell Biol. 1967, 35, 3, 521-552. Image made available by James D. Jamieson and the Department of Cell Biology, Yale University School of Medicine. (The Public Domain Mark is for works that are no longer restricted by copyright and can be freely used by others).

Every cell of $C$. reinhardtii possesses two flagella which it uses for swimming (movement). C. reinhardtii has a unique ability to turn on hydrogen production only to induce anaerobiosis in response to a metabolic stress. Aminoquinolines have a variety of biological properties including antimalarial, antileishmanial, antitrypanosomally, anticancer, antibacterial, antifungal, antialgal (possibly due to triggering of anaerobiosis), and antiviral (recently reported) (Ray et al., 2020), (Gao et al., 2020), (Liu et al., 2020) effects. Primaquine may bind to DNA and alter its properties. Effects on glycolysis (suboptimal doses of primaquine have been used in critically ill obese patients) (Santos et al., 2010), (Brian et al., 2020), influences on intracellular $\mathrm{pH}$, interference with the uptake of oxygen in the dark (respiration) and production of oxygen in light (photosynthesis) and interference with the electron transport chain in chloroplasts and mitochondria (Brondz et al., 2003), (Brondz et al., 2004a), (Brondz, 2011b). In vitro techniques in analysis of antimalarial drug primaquine (Historical Overview of Chromatography and Related Techniques in Analysis of Antimalarial Drug Primaquine) $7^{\text {th }}$ Annual BioMalPar Conference on the Biology and Pathology of the Malaria Parasite, 16-18 May 2011, (Heidelberg) Germany, abstr. 54, p. 80, have all been 


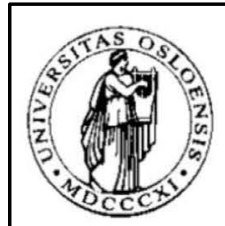

\section{In vitro techniques in analysis of antimalarial drug primaquine \\ Historical Overview of Chromatograhy and Related Techniques in Analysys of Antimalarial Drug Primaquine}

\section{Ilia Brondz}

University of Oslo, Department of Biology, P.O. Box 1066 Blindern, 0316 Oslo, Norway

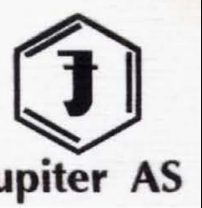

\section{INTRODUCTION}

Multiple toxic effects of primaquine such as neurotoxicity and methemoglobinemia in the not Caucasian race, has been described since it was in use. The biological activity of enantiomers of primaquine is in general well established. Schmidt et al., found that the capacities of the isomers and the racemate to cure infections with $P$. cynomolgi in rhesus monkeys were essentially identical. On the other hand, in the same investigation, conflicting evidence was also presented concerning the toxicity of $d$ - and $l$-isomer in rhesus monkeys versus mice. However, the question about the nature of the "related substances" to primaquine and they toxicity in terms of content of the actual related substances are never discussed in Pharmacopoeias. Dr. H. Frischer suggested the unifying hypothesis of the biochemical toxicology of primaquine. From the hypothesis it is clear that primaquine can participate in oxygen metabolism. 8-Aminoquinolines interfere with redox processes, primaquine can also induce superoxide production. Oxygen production was therefore chosen as the indication of toxicity.

Tab. 1

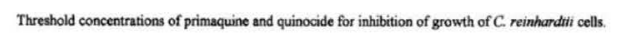

\begin{tabular}{|c|c|c|c|c|c|c|c|c|}
\hline \multirow[b]{2}{*}{ Concentration, mM } & \multirow{2}{*}{$\begin{array}{c}\text { Control } \\
0.00\end{array}$} & \multicolumn{3}{|c|}{ Primaquine batch 16039} & \multicolumn{2}{|c|}{ Primaquine batch 20107} & \multicolumn{2}{|c|}{ Quinocide batch 1717} \\
\hline & & 0.0001 & 0.0002 & 0.0004 & 0.0001 & 0.0002 & 0.0001 & 0.0002 \\
\hline $\begin{array}{l}\text { Cells/ml } \\
\cdot \text { Chlorophyll }\end{array}$ & $7.0 \times 10^{\circ}$ & $4.7 \times 10^{6}$ & $1.3 \times 10^{5}$ & $0.7 \times 10^{6}$ & $2.4 \times 10^{6}$ & $0.7 \times 10^{6}$ & $2.2 \times 10^{6}$ & $0.3 \times 10^{6}$ \\
\hline$(\mathrm{a}+\mathrm{b}) \mathrm{mg} / \mathrm{ml}$ & 2.4 & 2.0 & 0.6 & 0.1 & 1.1 & 0.3 & 1.0 & 0.1 \\
\hline
\end{tabular}

Cell numbers were $0.15 \times 10^{4}$ per $\mathrm{ml}$ at the start of the experiment. Number of cells and concentrations of chlorophyll $(a+b)$ given in the table were determined after 3 days of growth in the present of primaquine and quinocide at the indicated concentrations.

in $=5$, RSD $=3 \%$.

$$
\text { Tab. } 2
$$

The effect of primaquine and quinocide on oxygen metabolism of $C$, reinharditi in the dark and in light. Negative and positive numbers refer to uptake and evolution of oxygen, respectively.

$\mathrm{O}_{2}$ uptake $(-)$ or evolution $(+) \mathrm{nmol} \mathrm{O}_{2} / \mathrm{min} \times \mathrm{mg} \mathrm{Ch}$

\begin{tabular}{lcccc}
\hline & Dark & $\Delta^{*}$ & Light & $\Delta$ \\
Control & -7.2 & & +14.0 & \\
Primaquine $1.5 \mathrm{mM}$ & -6.2 & $-14 \%$ & -23.8 & $-263 \%$ \\
Quinocide $1.5 \mathrm{mM}$ & -5.3 & $-26 \%$ & -16.0 & $-214 \%$
\end{tabular}

$\Delta$ - Oxygen production/consumption \% difference between control and sample with $1.5 \mathrm{mM}$ primaquine or quinocide.

$n=9$, RSD $-5 \%$.

\section{MATERIALS AND METHODS} toxicity of primaquine (containing $0.3 \%$ of ocide), the industrial drug primaquine the quinocide.

\section{RESULTS AND DISCUSSION}

The substances were toxic (algaecidal) at maquine batch $16039,1.0 \times 10^{-4} \mathrm{mg} / \mathrm{mL}$ for in dark (respiration) and production of oxygen stances had measurable inhibitory effects on oxygen consumption in the dark, (Tab. 2), but they abolished evolution of oxygen in the light

\section{CONCLUSION}

Both substances induced a net uptake of oxygen in the light (Tab. 2), but, more conspicuously, they abolished evolution of oxygen in the light. Moreover, both substances induced a net uptake of oxygen in the light, at rates were 2 to 3 times higher than oxygen uptake of the control cells in the dark. The effect resembles the enhanced uptake of oxygen that observed with uncouplers of respiration. Because primaquine and

quinocide reverse oxygen production in the light to oxygen consumption, these substances seem to interfere with the photosynthetic electron transport chain in the chloroplast of the algae. The toxic effect of the quinocide and primaquine against algae show that the quinocide is about twice as toxic as primaquine [1]

\section{REFERENCES}

Ilia Brondz. Dimitris Mantzilas. Uwe Klein. Dag Ekeberg, Erlend Hvattum. Marina N. Lebedeva, Felix S. Mikhailitsyn, Gasan D. Souleimanov, Johan Roe, Nature of the main contaminant in the anti malaria drug primaquine di-phosphate: a qualitative isomer analysis, Journal of Chromatography B, 800 (2004) pp. 211-223.

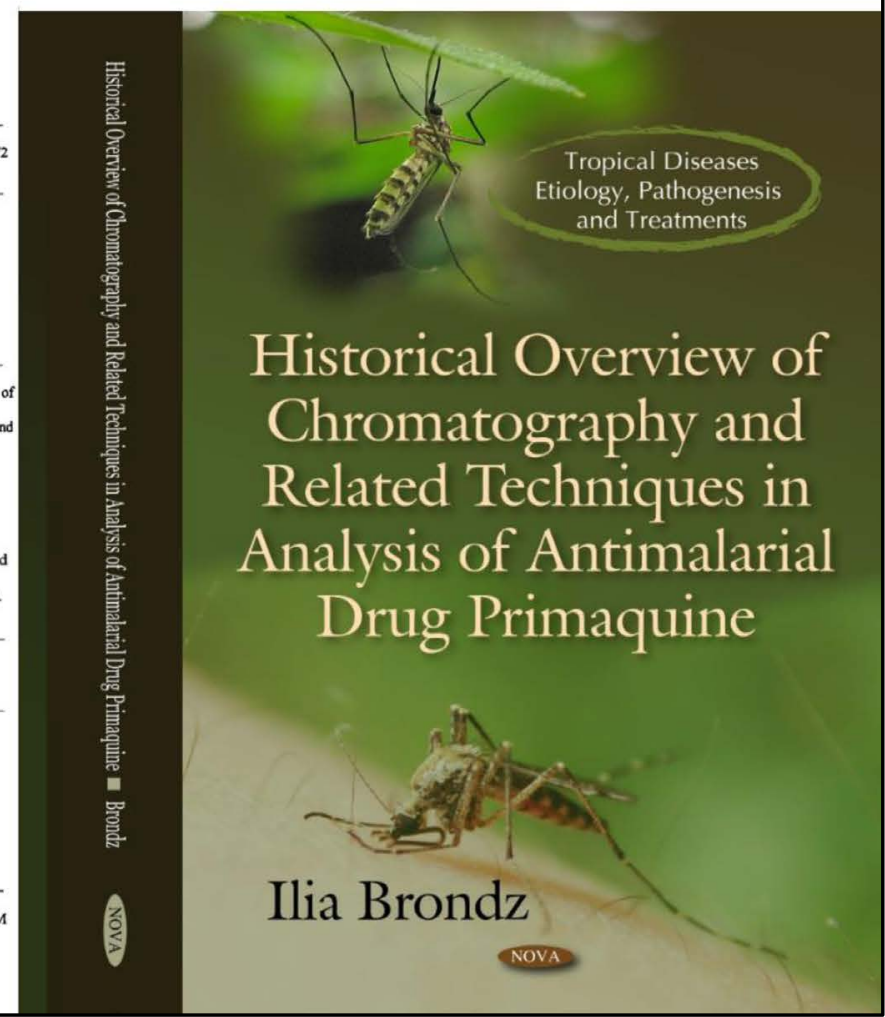

Figure 5. The table of toxic effects of primaquine and quinocide (reproduced from Brondz, 2011b

[https://www.researchgate.net/publication/264346815_In_vitro_techniques_in_analysis_of_antimalarial_drug_primaquine_Hi storical_Overview_of_Chromatography_and_Related_Techniques_in_Analysis_of_Antimalarial_Drug_Primaquine]). 


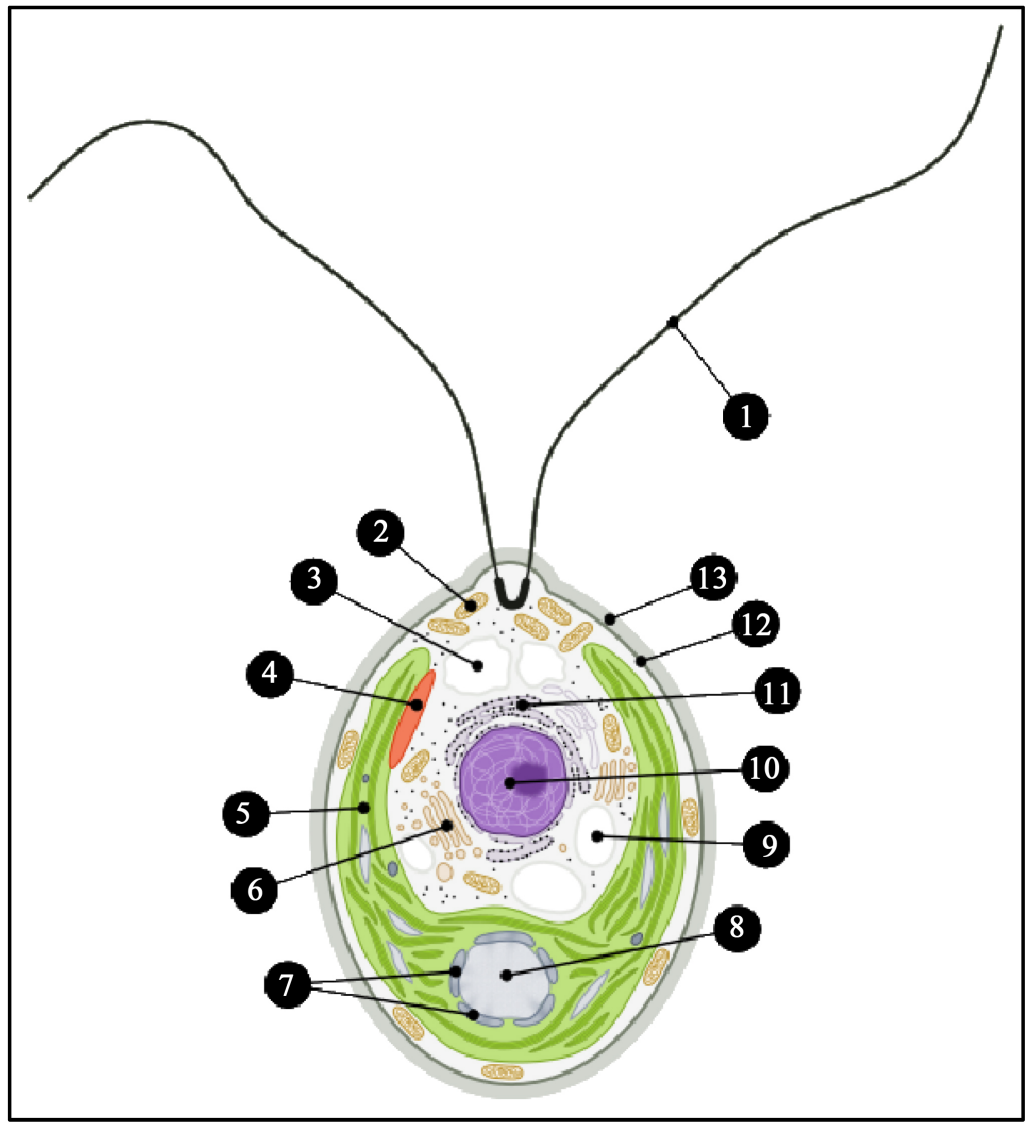

Figure 6. The scheme of the Chlamydomonas reinhardtii redroawn from TEM micrograph: http://cellimagelibrary.org/images/CIL_37252.

reported. Aminoquinolines can impair the overall bioenergetic metabolism of cells, causing a rapid drop in intracellular ATP levels without affecting plasma membrane permeability. By this mechanism, they induce mitochondrial dysfunction through the inhibition of cytochrome $\mathrm{C}$ reductase (respiratory complex III) with a decrease in the oxygen consumption rate and depolarization of mitochondrial membrane potential.

C. reinhardtii is a motile flagellated microalga. Flagellated movements are usually mediated by a hydrogen-proton motor. The arrest of $C$. reinhardtii movement by primaquine and quinocide may suggest the deactivation of this hydrogen-proton motor (Brondz et al., 2003), (Brondz et al., 2004a), (Brondz, 2011a), (Brondz, 2011b). Disruption of the hydrogen-proton motor suggests proton-pump inhibition. By this mechanism, the 8-aminoquinolines primaquine and quinocide and other 4-aminoquinolines may be candidates for selective targeting of COVID-19 replication (Watanabe et al., 2020), (Shin et al., 2004).

\section{Hypericum perforatum L.}

The content and biological activities of $H$. perforatum L. were studied at Oslo University by Brondz and reported in his thesis for the degree of Candidatus of Pharmaceutical sciences: (Brondz, I. In: Antibiotikumet "Hyperforin" ogan- 
dreinnholdsstoffer i drogen Hypericum perforatum L., (1979) Thesis (Cand. Pharm.) University of Oslo, Oslo Norway (in Norwegian)) (Brondz, 1979) (text is available from the University library). The content of $H$. perforatum $\mathrm{L}$. was described and published in (Brondz et al., 1983a), (Brondz et al., 1983b). The $n$-alkenes were isolated from $H$. perforatum L. by truping (clathrating) using urea crystals (Figure 7) and identified using chromatography (Figure 8) (Brondz, 1979).

Special attention was directed to the study of the stereochemistry and antimicrobial activities of hyperforin. Hyperforin was isolated, its molecular mass was first established using MS with chemical ionization (Figure 9), and its antimicrobial activity against penicillin-resistant bacteria was demonstrated (Brondz, 1979).

The correct stereochemistry of this biologically active molecule is especially important for its pharmacological effects on enzymes and on the immune system. The relative and absolute stereochemistry of hyperforin was published previously by the Shemyakin Institute of Bio-organic Chemistry (USSR Academy of Sciences in Moscow) in 1975 (Bystrov et al., 1976), (Bystrov et al., 1975). In another study (Brondz et al., 1982) the relative stereochemistry was supported by Brondz et al., X-ray diffraction measurements, however, the absolute configuration of hyperforin as determined at the USSR Academy of Sciences in Moscow (Bystrov et al., 1976), (Bystrov et al., 1975) was incorrect. The correct absolute configuration of hyperforin was reported based on the crystal structure determination of hyperforin $p$-bromobenzoate ester based on X-ray diffraction measurements (Brondz et al., 1983a), (Brondz, 2016a). Other studies (Brondz, 2017a), (Brondz, 2017b), (Brondz, 2018) compared this version of the absolute configuration of hyperforin with that reported in (Bystrov et al., 1976) and (Bystrov et al., 1975) (Figure 10) and found that the correct absolute configuration of hyperforin was that first described in (Brondz et al., 1983a) and was supported in (Brondz, 2017b).
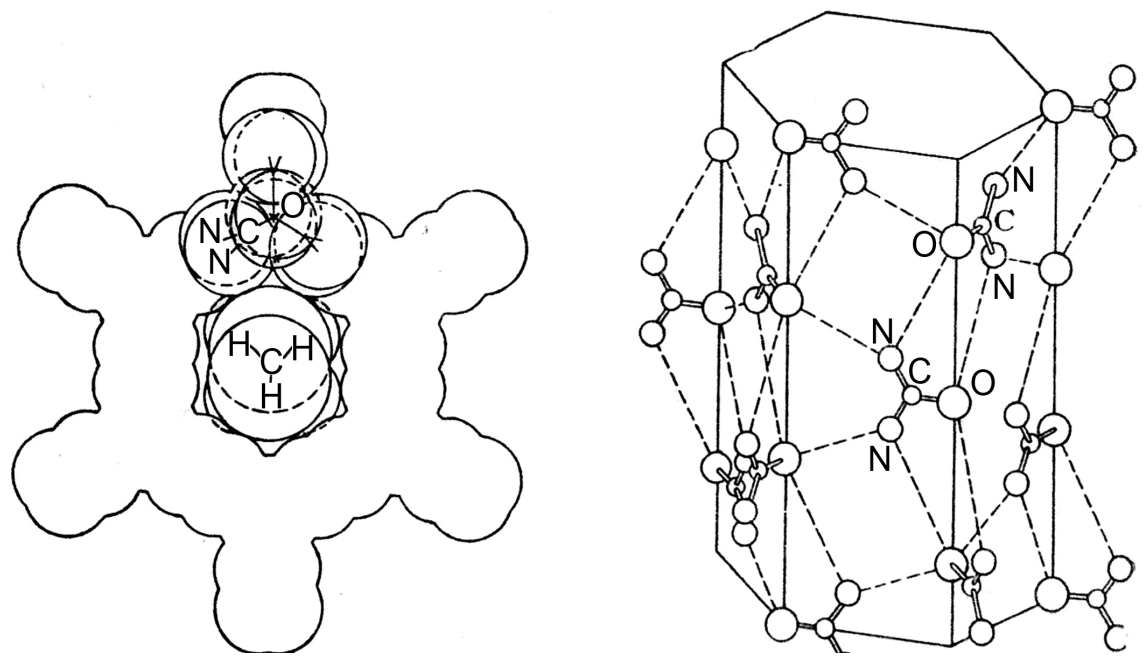

Figure 7. Clathrates of $n$-alkanes in urea (Brondz, 1979). 


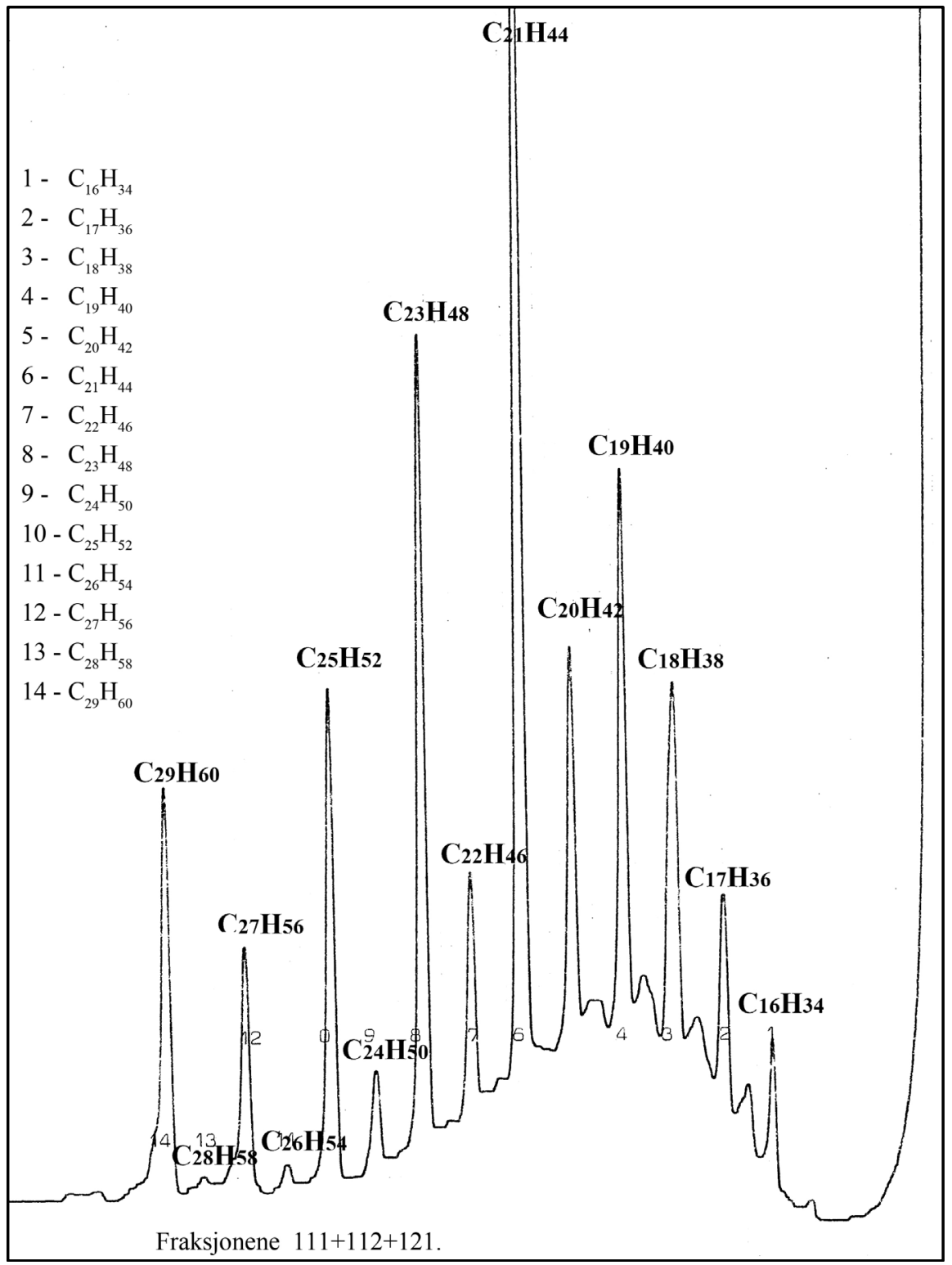

Figure 8. Content of $n$-alkanes in $H$. perforatum L. (Brondz, 1979).

\subsection{Hyperforin's Antimicrobial and Immunomodulating Properties}

The antimicrobial spectrum of hyperforin (is including that against penicillin-resistant bacteria) was described in (Brondz, 1979); later, it was reported that hyperforin had antimicrobial activity against multiresistant Staphylococcus and Neisseria meningitidis. The possibility of immunomodulatory effects of the drug was first suggested by Brondz in a lecture at the Symposium: Norlændska infektionssjkdomar, Sweden (1986), entitled "The influence of hyperforin on phagocytosis of $E$. coli by human polymorphonuclear neutrophils in vitro." However, data about the phagocytosis of $E$. coli by human polymorphonuclear neutrophils (in vitro) was reported by Brondz et al. as early as 1984 (Brondz et al., 1984). Later developments of the research were reported in (Brondz, 1987). 


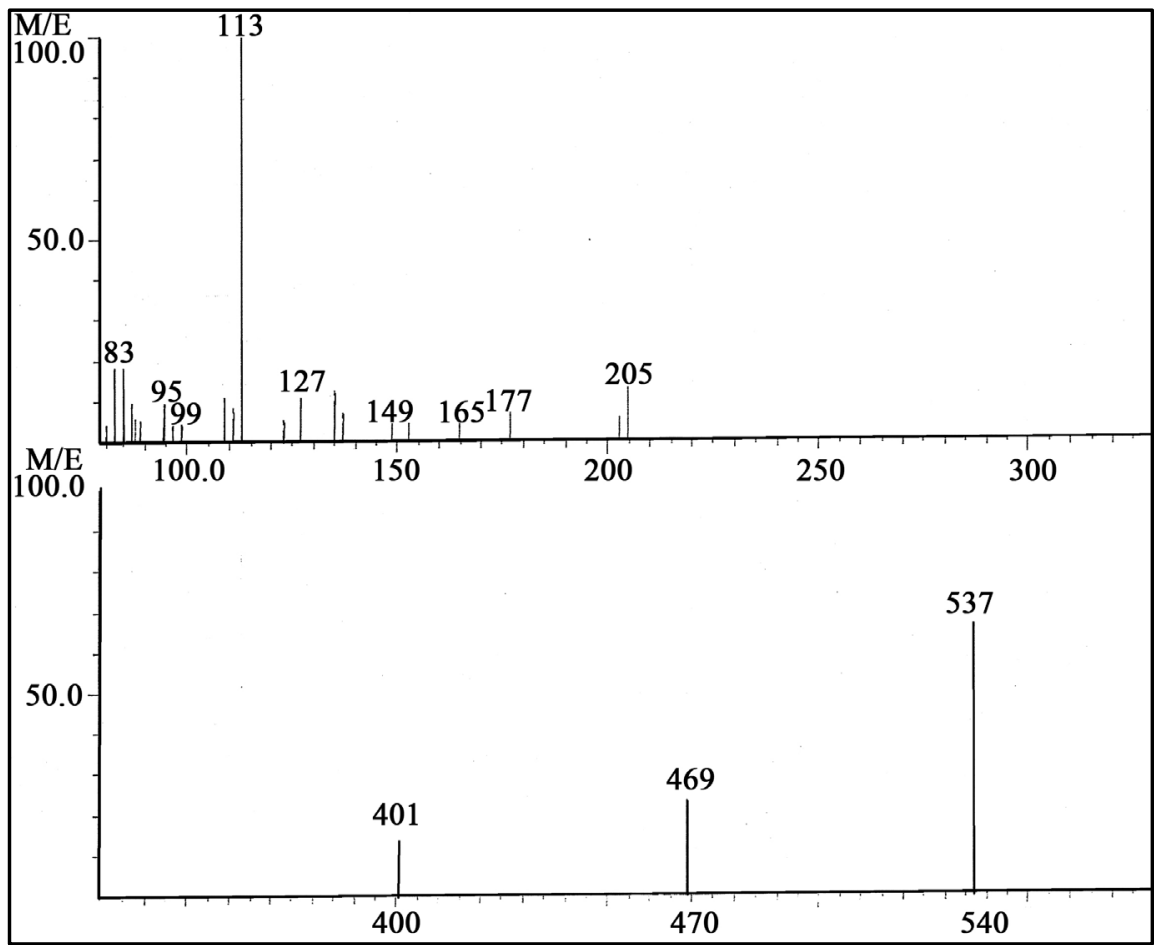

Figure 9. First available mass spectrum of hyperforin (Brondz, 1979).

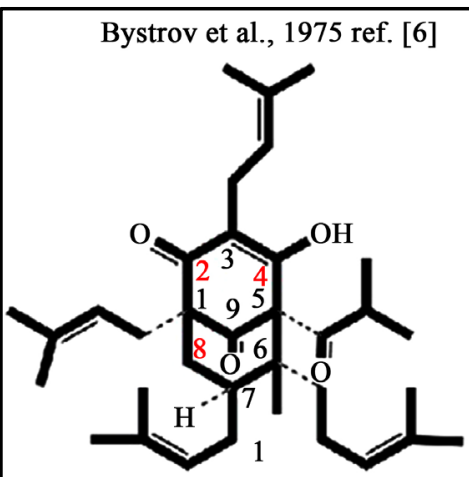

(1S,5R,6R,7S)-4-hydroxy-5-isobutyryl6-methyl-1,3,7-tris(3-methylbut-2-en1-yl)-6-(4-methylpent-3-en-1-yl)bicyclo [3.3.1]non-3-ene-2,9-dione

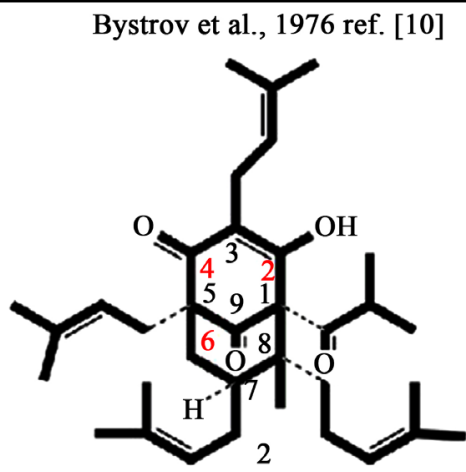

2-hydroxy-1-isobutyryl8-methyl-3,5,7-tris(3-methylbut-2-en1-yl)-8-(4-methylpent-3-en-1-yl)bicyclo [3.3.1]non-3-ene-4,9-dione

Bystrov et al., 1976 ref. [11]

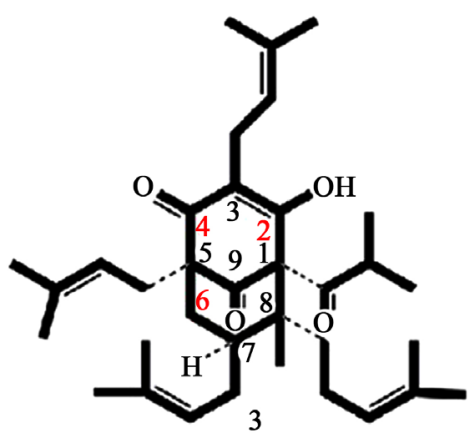

Figure 10. Absolute stereochemistry reported by Bystrov et al. (reproduced from Brondz, 2018). 


\subsection{Enhancement of Immunity}

The antimicrobial and immunomodulatory properties of hyperforin are especially important in meningococcal diseases, syphilis, and gonorrhea. Hyperforin, a substance from the herb H. perforatum L. (Brondz, 1979) is an immunomodulator (Brondz, 2016a), (Brondz, 1987), (Brondz, 2012), (Brondz \& Brondz, 2012b), (Brondz, 2016b) (without suppressing the immune system). Its importance in curing the meningococcal diseases, syphilis, and gonorrhea difficult overestimate.

\subsection{Lysozyme and Hyperforin Enhancement of Immunity and Activity against Viruses}

Most antibiotics, antimycotics, cytostatic drugs, and antivirals have negative effects on the immune system. Commercially available treatments with exogenous and endogenous lysozyme can enhance the immune system and have antiviral effects (Oderinde et al., 2017), (Cisani et al., 1984), (Lee-Huang et al., 1999). Hyperforin has antimicrobial (Brondz, 1979) and immunostimulating effects (Brondz, 2016a), (Brondz, 1987). Influence of hyperforin upon phagocytic functions in human polymorphonuclear leucocytes was presented at Fourth International Conference on Chemistry and Biotechnology of Biological Active Natural Products, (Budapest) Hungary (1987) abstr. B-15, p. 119 (Brondz, 1987). Enhancement of the immunity in AIDS and other immunocompromised patients by hyperforin an antibiotic from Hypericum perforatum $\mathrm{L}$. was also presented at $2^{\text {nd }}$ ARIP European Conference on Antimicrobial Resistance \& Infection Prevention, Vilnius, Lithuania, 4-5 October 2012, P12, p. 60. In: (Brondz, 2012) OFICIALUS LIETUVOS BENDROSIOS PRAKTIKOS GYDYTOJŲ KOLEGIJOS LEIDINYS, No. 7, ISSN, pp. 1392-3218. Hyperforin penetrates the BTB and the BBB (Brondz, 2016b), and accumulates in vital tissues including the liver, lungs, kidney, skin, testis, and brain (Brondz, 2016b). Hyperforin has activity against plant viruses (Brondz, 1979). However, more important is the discovery that it has antiviral activity against animal viruses (Verotta et al., 2007), (Huijie et al., 2019) and is active against the causative agent of COVID-19, SARS-CoV-2.

\section{Conclusion}

The use of harmful practices in the agriculture, farming of livestock, poultry, and fish, and in food processing must be avoided. Forest arsonists as well as the users of "fire farming" and the manufacturers of food with added toxic substances must be punished because they are jeopardizing the health of the global population. The reasons why medication with known antiviral (anti-COVID-19) drugs including 4-aminoquinolines, 8-aminoquinolines, lysozyme, hyperforin (Bajrai, et al., 2021), and other drugs has been not used during the wait for suspicious, incompletely developed, and not clinically tested vaccines should be investigated and questioned. Why wait for an illusory vaccine when several millions of humans have died globally, and not use the same medications that were used to 
treat former President Donald Trump, who was healthy two days after COVID-19 infection [https://www.youtube.com/watch?v=BqeNqEAE3R0]? The proposal and prediction that vaccination against COVID-19 infection must be repeated every six months for the majority of the population rather than using antiviral drugs show that vaccination is not sustainable, and it is most likely directed to aims other than protecting the global population from illness.

\section{Conflicts of Interest}

The author declares no conflicts of interest regarding the publication of this paper.

\section{References}

Bajrai, L. H., El-Kafrawy, S. A., Alnahas, R. S., \& Azhar, E. I. (2021). In Vitro Screening of Anti-Viral and Virucidal Effects against SARS-CoV-2 by Hypericum perforatum and Echinacea. https://www.biorxiv.org/content/10.1101/2021.01.11.426295v1 https://doi.org/10.1101/2021.01.11.426295

Brian, L., Erstad, B. L., Jeffrey, F., \& Barletta, J. F. (2020). Drug Dosing in the Critically Ill Obese Patient-A Focus on Sedation, Analgesia, and Delirium. Critical Care, 24, 315. https://doi.org/10.1186/s13054-020-03040-Z

Brondz, I. (1979). Antibiotikumet "Hyperforin" ogandreinnholdsstoffer i drogen Hypricum perforatum L. Thesis (Cand. Pharm.), University of Oslo. (In Norwegian)

Brondz, I. (1987). Influence of Hyperforin upon Phagocytic Functions in Human Polymorphonuclear Leucocytes. Fourth International Conference on Chemistry and Biotechnology of Biological Active Natural Products, Budapest, 10-14 August 1987, 119. https://www.researchgate.net/publication/233795016_The_influence_of_hyperforin_o n_phagocytosis_of_Ecoli_by_human_polymorphonuclear_neutrophils_in_vitro

Brondz, I. (2009a). Chap. 5. SFC-MS Analysis of Contaminants in Primaquine Diphosphate Tablets and Spectral UV and NMR Characterizing of Primaquine and Quinocide. In E. Csizmadia, \& I. Kalnoky (Eds.), Antimalarial Drugs: Costs, Safety, and Efficacy (pp. 105-124). Nova Science Publishers, Inc.

Brondz, I. (2009b). Improved Separation of Quinocide in Primaquine Analysis by Supercritical Fluid Chromatography-Mass Spectrometry. 5th Conference Nordic Separation Science Society, Tallinn, 26-29 August 2009, 6.

Brondz, I. (2010). Chapter 6. Historical Overview of Chromatography and Related Techniques in Analysis of Antimalarial Drug Primaquine. In T. J. Quintin (Ed.), Chromatography: Types, Techniques and Methods (pp. 281-322). Nova Science Publishers, Inc.

Brondz, I. (2011a). Historical Overview of Chromatography and Related Techniques in Analysis of Antimalarial Drug Primaquine. Nova Science Publishers, Inc.

Brondz, I. (2011b). In Vitro Techniques in Analysis of Antimalarial Drug Primaquine (Historical Overview of Chromatography and Related Techniques in Analysis of Antimalarial Drug Primaquine). 7th Annual BioMalPar Conference on the Biology and Pathology of the Malaria Parasite, Heidelberg, 16-18 May 2011, 80.

Brondz, I. (2011c). SFC-MS Analysis of Contaminants in Primaquine Diphosphate Tablets and Spectral UV and NMR Characterizing of Primaquine and Quinocide. Journal of Malaria Research, 2, 181-200.

Brondz, I. (2012). Enhancement of the Immunity in AIDS and Other Immunocompromised Patients by Hyperforin an Antibiotic from Hypericum perforatum L. 2nd ARIP 
European Conference on Antimicrobial Resistance \& Infection Prevention, Vilnius, 4-5 October 2012, 60 .

https://www.researchgate.net/publication/233782215_Enhancement_of_the_immuity_i n_AIDS_and_other_immunocompromised_patients_by_hyperforin_anantibiotic_fro m_Hypericum_perforatum_L

Brondz, I. (2014). Review: Can Toxic Substances Initiate Psychotic Behavior? Part I. Antimalarial Drugs. Open Journal of Preventive Medicine, 4, 561-572.

https://doi.org/10.4236/ojpm.2014.47066

Brondz, I. (2016a). Super Antibiotics, Part I. Hyperforin. Voice of the Publisher, 2, 19-27. https://doi.org/10.4236/vp.2016.24004

Brondz, I. (2016b). Super Antibiotics, Part II. Hyperforin, Mass Spectroscopy (MS) and Gas Chromatography-Mass Spectrometry (GC-MS), Evidence of Permeability of the Blood-Testis Barrier (BTB) and the Blood-Brain Barrier (BBB) to Hyperforin. International Journal of Analytical Mass Spectrometry and Chromatography, 4, 66-73. https://doi.org/10.4236/ijamsc.2016.44007

Brondz, I. (2017a). Super Antibiotics, Part IV. Hyperforin, Relative and Absolute Stereochemistry Elucidated by Gas-Chromatography Mass-Spectrometry with Supersonic Molecular Beams. International Journal of Analytical Mass Spectrometry and Chromatography, 5, 70-85. https://doi.org/10.4236/ijamsc.2017.53005

Brondz, I. (2017b). Super Antibiotics: Part III. Hyperforin, Revision of the Relative and Absolute Stereochemistry Presented by Bystrov et al. Voice of the Publisher, 3, 15-24. https://doi.org/10.4236/vp.2017.32002

Brondz, I. (2017c). To Be or Not to Be...? Part I: Is Global Climate Change a Future Reality? Voice of the Publisher, 3, 25-33. https://doi.org/10.4236/vp.2017.33003

Brondz, I. (2018). Super Antibiotics, Part VI: Hyperforin, Revision of Stereochemistry. Short Communications. International Journal of Analytical Mass Spectrometry and Chromatography, 6, 37-39. https://doi.org/10.4236/ijamsc.2018.62003

Brondz, I. (2020). COVID-19 Pandemic, Part I: What to Do and Who to Blame? Susceptibility to Viral Infection via Jeopardized Immunity. International Journal of Analytical Mass Spectrometry and Chromatography, 8, 7-13. https://doi.org/10.4236/ijamsc.2020.82002

Brondz, I. (2021). Is Life Based on Chirality of Pentavalent Elements Possible? Resolution of Stable Isomers, Enantiomers and Diastereomers of Pentavalent Nitrogen. Voice of the Publisher, 7, 44-55. https://doi.org/10.4236/vp.2021.71004

Brondz, I., \& Brondz, A. (2011). Suppression of Immunity by Some Pesticides, Xenobiotics, and Industrial Chemicals. In Vitro Model. Journal of Biophysical Chemistry, 2, 226-232. https://doi.org/10.4236/jbpc.2011.23028

Brondz, I., \& Brondz, A. (2012a). Recent Enhancement of the Immunity in AIDS and Other Immunocompromised Patients by Hyperforin an Antibiotic from Hypericum perforatum L. (in Vitro Model) Part I. Journal of Biophysical Chemistry, 3, 304-310. https://file.scirp.org/pdf/JBPC20120400005_27606215.pdf https://doi.org/10.4236/jbpc.2012.34037

Brondz, I., \& Brondz, A. (2012b). The Technology for Preparation of Generic (Monoenantiomeric) Antimalarial Drug Primaquine by Using Supercritical Fluid Chromatography. Separation of Primaquine from Quinocide: Simultaneous Resolution of the Enantiomers of Primaquine and Their Separation from Quinocide in One Run. American Journal of Analytical Chemistry, 3, 884-890.

https://doi.org/10.4236/ajac.2012.312A117

Brondz, I., \& Klein, U. (2005). Separation of the Positional Isomer Quinocide from the 
Anti-Malarial Drug Primaquine Using a Discovery ${ }^{\circledast}$ HS F5 HPLC Column. The Reporter, 23, 1 .

Brondz, I., \& Klein, U. (2006). Separation of the Positional Isomer Quinocide from the Anti-Malarial Drug Primaquine Using a Discovery HS F5 HPLC Column. The Reporter, 19, 3.

Brondz, I., Greibrokk, T., Groth, P. A., \& Aasen, A. J. (1982). The Relative Stereochemistry of Hyperforin-An Antibiotic from Hypericum perforatum L. Tetrahedron Letters, 23, 1299-1300. https://doi.org/10.1016/S0040-4039(00)87088-4

Brondz, I., Greibrokk, T., \& Aasen, A. J. (1983a). n-1-Alkohols of Hypericum perforatum. Journal of Natural Products, 46, 940-941. https://doi.org/10.1021/np50030a025

Brondz, I., Greibrokk, T., \& Aasen, A. J. (1983b). n-Alkanes of Hypericum perforatum: A Revision. Phytochemistry, 22, 295-296. https://doi.org/10.1016/S0031-9422(00)80110-7

Brondz, I., Greibrokk, T., Groth, P., \& Aasen, A. J. (1983c). The Absolute Configuration of Hyperforin, an Antibiotic from Hypericum perforatum L., Based on the Crystal Structure Determination of Its $p$-Bromobenzoate Ester. Acta Chemica Scandinavica, A37, 263-265. https://doi.org/10.3891/acta.chem.scand.37a-0263

https://www.semanticscholar.org/paper/The-Absolute-Configuration-of-Hyperforin\%2 C-an-from-Brondz-Greibrokk/451d077fea3e32018cd860a2ecea2544a93ee957

Brondz, I., Lingaas, E., Olssen, I., \& Midtvedt, T. (1984). The Influence of Hyperforin on Phagocytosis of Escherichia coli by Human Polymorphonuclear Neutrophils in Vitro. 14th International Symposium on the Chemistry of Natural Products, Poznan, 9-14 July 1984, 590.

https://www.researchgate.net/publication/308416639_The_Influence_of_Hyperforin_o n_phagocytosis_of_Escherichia_coli_by_human_polymorphonuclear_neutrophils_in vitro\#fullTextFileContent

Brondz, I., Mantzeilas, D., Klein, U., Lebedeva, M. N., Mikhailitsyn, F. S., Souleimanov, G. D., \& Ekeberg, D. (2003). The Main Contaminant of the Anti-Malaria Drug Primaquine Is Its Positional Isomer. 3rd International Symposium on Separation in BioSciences SBS 2003 a 100 Years of Chromatography, Moscow, 13-18 May 2003, 165.

Brondz, I., Mantzilas, D., Klein, U., Ekeberg, D., Hvattum, E., Lebedeva, M. N., Mikhailitsyn, F. S., Souleimanov, G. D., \& Røe, J. (2004a). Nature of the Main Contaminant in the Anti-Malaria Drug Primaquine Di-Phosphate: A Qualitative Isomer Analysis. Chromatography B: Biomedical Sciences and Applications, 800, 211-223. https://doi.org/10.1016/j.jchromb.2003.09.042

Brondz, I., Klein, U., Ekeberg, D., Mantzilas, D., Hvattum, E., Schultz, H., \& Mikhailitsyn, F. S. (2004b). International Symposium Analytical Forum 2004, Nature of the Main Contaminant in the Anti-Malaria Drug Primaquine Di-Phosphate: GC-MS Analysis, 4-8 July, Warsaw, Poland, 2004 (p. 154).

Brondz, I., Klein, U., Ekeberg, D., Mantzilas, D., Hvattum, E., Schultz, H., \& Mikhailitsyn, F. S. (2005a). Nature of the Main Contaminant in the Anti-Malaria Drug Primaquine Di-Phosphate: GC-MS Analysis. Asian Journal of Chemistry, 17, 1678-1688.

Brondz, I., Klein, U., Karaliova, L., Vlachos, V., Oakley, P., Leideborg, R., \& Mikhalitsyn, F. (2005b). Nature of the Main Contaminant in the Drug Primaquine Di-Phosphate. Comparison of HPLC and SFC Methods. 29th International Symposium on High Performance Liquid Phase Separations and Related Techniques, Stockholm, 26-30 June $2005,43$.

Brondz, I., Ekeberg, D., Karaliova, L., Jennings, I., Hustad, J. A., \& Svendsen, R. (2005c). Separation of the Positional Isomer Quinocide from the Anti-Malaria Drug Primaquine Using a Discovery ${ }^{\circledast}$ HS-F5 HPLC Column. Trends in Chromatography, 1, 78-81. 
Brondz, I., Ekeberg, D., Bell, D. S., Hustad, J. A., Svendsen, R., Vlachos, V., Oakley, P., Langley, G. J., Mohini, T., Amaury, C.-G., \& Mikhalitsyn, F. (2007). Nature of the Main Contaminant in the Drug Primaquine Diphosphate: SFC and SFC-MS Methods of Analysis. Journal of Pharmaceutical and Biomedical Analysis, 43, 937-944. https://doi.org/10.1016/j.jpba.2006.09.017

Brondz, I., Fialkov, A. B., \& Amirav, A. (2009). Analysis of Quinocide in Unprocessed Primaquine Diphosphate and Primaquine Diphosphate Tablets Using Gas Chromatography-Mass Spectrometry with Supersonic Molecular Beams. Journal of Chromatography A, 1216, 824-829. https://doi.org/10.1016/j.chroma.2008.11.043

Bystrov, N. S., Chernov, B. K., Dobrynin, V. N., \& Kolosov, M. N. (1975). The Structure of Hyperforin. Tetrahedron Letters, 16, 2791-2794. https://doi.org/10.1016/S0040-4039(00)75241-5

Bystrov, N. S., Gupta, Sh. R., Dobrynin, V. N., Kolosov, M. N., \& Chernov, B. K. (1976). Structure of the Antibiotic Hyperforin. Doklady Akademii Nauk SSSR, 226, 88-90. (In Russian)

Carlson, C. J., Dougherty, E. R., \& Getz, W. (2016). An Ecological Assessment of the Pandemic Threat of Zika Virus. PLOS Neglected Tropical Diseases, 10, e0004968. https://doi.org/10.1371/journal.pntd.0004968

Cisani, G., Varaldo, P. E., Ingianni, A., Pompei, R., \& Satta, G. (1984). Inhibition of Herpes Simplex Virus-Induced Cytopathic Effect by Modified Hen Egg-White Lysozymes. Current Microbiology, 10, 35-40. https://doi.org/10.1007/BF01576045

Darvin, C. M. A. (1859). On the Origin of Species. John Murray. https://en.wikipedia.org/wiki/On_the_Origin_of_Species\#/media/File:Origin_of_Speci es_title_page.jpg

Freeman, R. B. (2002). The Works of Charles Darwin: An Annotated Bibliographical Handlist. In J. Van Wyhe (Ed.), On the Origin of Species. Darwin Online.

http://test.darwin-online.org.uk/EditorialIntroductions/Freeman_OntheOriginofSpecie s.html

Gao, J., Tian, Z., \& Yang, X. (2020). Breakthrough: Chloroquine Phosphate Has Shown Apparent Efficacy in Treatment of COVID-19 Associated Pneumonia in Clinical Studies. Bioscience Trends, 14, 72-73. https://doi.org/10.5582/bst.2020.01047

Huijie, C. et al. (2019). Antiviral Activity against Infectious Bronchitis Virus and Bioactive Components of Hypericum perforatum L. Frontiers in Pharmacology, 10, 1272.

Klein, J., \& Klein, N. (2013). Solitude of a Humble Genius-Gregor Johann Mendel (Volume 1). Springer. https://doi.org/10.1007/978-3-642-35254-6

Lambert, N., Strebel, P., Orenstein, W., Icenogle, J., \& Poland, G. A. (2015). Rubella. The Lancet, 9984, 2297-307. https://doi.org/10.1016/S0140-6736(14)60539-0

Lee-Huang, S., Huang, P. L., Sun, Y., Kung, H. F., Blithe, D. L., \& Chen, H. C. (1999). Lysozyme and RNases as Anti-HIV Components in Beta Core Preparations of Human Chorionic Gonadotropin. Proceedings of the National Academy of Sciences (USA), 96, 2678-2682. https://doi.org/10.1073/pnas.96.6.2678

Liu, J., Cao, R., Xu, M., Wang, X., Zhang, H., Hu, H., Li, Y., Hu, Z., Zhong, W., \& Wang, M. (2020). Hydroxychloroquine, a Less Toxic Derivative of Chloroquine, Is Effective in Inhibiting SARS-CoV-2 Infection in Vitro. Cell Discovery, 6, 269. https://doi.org/10.1038/s41421-020-0156-0

Mattes, F. M., McLaughlin, J. E., Emery, V. C., Clark, D. A., \& Griffiths, P. D. (2000). Histopathological Detection of Owl's Eye Inclusions Is Still Specific for Cytomegalovirus in the Era of Human Herpesviruses 6 and 7. Journal of Clinical Pathology, 53, 8. https://doi.org/10.1136/jcp.53.8.612 
Michael, M. (1908). Rubella: Report of Epidemic of Eighty Cases. In Textbook of Pediatric Infectious Diseases (Vol. 2). Saunders.

Minami, J., Odamaki, T., Hashikura, N., Abe, F., \& Xiao, J. Z. (2015). Lysozyme in Breast Milk Is a Selection Factor for Bifidobacterial Colonisation in the Infant Intestine. Beneficial Microbes, 7, 53-60. https://doi.org/10.3920/BM2015.0041

Oderinde, B. S., Agbede, O. O., Iheukwumere, I. N., Ghamba, P. E., Medugu, J. T., \& Oku, E. I. (2017). Antiviral Activity of Hen Egg-White Lysozyme on Polio Virus. Sokoto Journal of Medical Laboratory Science, 2, 109-120.

Ray, A., Sharma, S., \& Sadasivam, B. (2020). The Potential Therapeutic Role of Proton Pump Inhibitors in COVID-19: Hypotheses Based on Existing Evidences. Drug Research (Stuttg), 70, 484-488. https://doi.org/10.1055/a-1236-3041

Santos, J. B., Luz, F. das C. de O., Deckers, F. A. L., \& Tauil, P. L. (2010). Subdoses of Primaquine in Overweight Patients and Malaria vivax Relapses: Report of Two Cases in the Federal District, Brazil. Revista da SociedadeBrasileira de Medicina Tropical, 43, 749-750. https://doi.org/10.1590/S0037-86822010000600033

Schacherer, J. (2016). Beyond the Simplicity of Mendelian Inheritance. Comptes Rendus Biologies, 339, 7-8. https://doi.org/10.1016/j.crvi.2016.04.006

Shin, J. M., Cho, Y. M., \& Sachs, G. (2004). Chemistry of Covalent Inhibition of the Gastric $\left(\mathrm{H}^{+}, \mathrm{K}^{+}\right)$-ATPase by Proton Pump Inhibitors. Journal of American Chemical Society, 126, 7800-7811. https://doi.org/10.1021/ja049607w

The Making of "Gutter Oil”. https://www.youtube.com/watch?v=zrv78nG9R04

Verotta, L., Appendino, G., Bombardelli, E., \& Brun, R. (2007). In Vitro Antimalarial Activity of Hyperforin, a Prenylated Acylphloroglucinol. A Structure-Activity Study. Bioorganic \& Medicinal Chemistry Letters, 17, 1544-1548.

https://doi.org/10.1016/j.bmcl.2006.12.100

Watanabe, S. M., Ehrlich, L. S., Strickland, M., Li, X., Soloveva, V., Goff, A. J., Stauft, C. B., Bhaduri-McIntosh, S., Tjandra, N., \& Carter, C. (2020). Selective Targeting of Virus Replication by Proton Pump Inhibitors. Scientific Reports, 10, Article No. 4003. https://doi.org/10.1038/s41598-020-60544-y 